\title{
Problematyka przestępstwa uporczywego nękania
}

\author{
Issues of the crime of persistent harassment
}

\begin{abstract}
STRESZCZENIE
Niniejszy artykuł przedstawia istotę przestępstwa uporczywego nękania stypizowanego w art. 190a k.k. Regulacje te poddane zostają szczegółowej analizie, której celem jest wskazanie rozumienia poszczególnych pojęć użytych przez ustawodawcę w omawianych przepisach, a także wskazanie kwestii problematycznych, w tym popełnienie przez ustawodawcę błędów przy konstruowaniu regulacji dotyczących przestępstwa uporczywego nękania, co powoduje, że przepis zawiera pewne zbędne elementy. Niemniej jednak, omawiane regulacje pomimo pewnych błędów należy uznać za niezbędne.
\end{abstract}

Slowa kluczowe: uporczywe nękanie; targnięcie się na własne życie; kodeks karny

\section{WSTĘP}

Uporczywe nękanie jest penalizowane w porównaniu z innymi przestępstwami od dość niedawna. Nowela wprowadzająca nowy typ czynu zabronionego jakim jest uporczywe nękanie uchwalona została dnia 25 lutego 2011 roku$^{1}$, zaś zmiany weszły w życie dnia 6 czerwca 2011 roku. Ratio legis penalizacji uporczywego nękania była rosnąca skala tegoż zjawiska². Regulacje dotyczące penalizacji zjawiska uporczywego nękania zostały umiejscowione w art. 190a k.k. ${ }^{3}$.

Niewątpliwie penalizacja uporczywego nękania była trafna, biorąc pod uwagę zwłaszcza fakt, że nie jest to zjawisko mające marginalny charakter. Świadczą

1 Ustawa z dnia 25 lutego 2011 r. o zmianie ustawy - Kodeks karny (Dz. U. z 2011 r. Nr 72, poz. 381).

2 Uzasadnienie do projektu ustawy zmieniającej Ustawę z dnia 6 czerwca 1997 r. - Kodeks karny z 31 sierpnia $2011 \mathrm{r}$. (Sejm VI kadencji, druk nr 3553), s. 2-3.

3 Ustawa z dnia 6 czerwca 1997 r. - Kodeks karny (Dz.U. z 2018 r., poz. 1600), dalej: k.k. 
o tym chociażby statystyki Informatora Statystycznego Wymiaru Sprawiedliwości zgodnie, które wskazują na liczba wyroków skazujących za popełnienie czynu zabronionego z art. 190a $\S 1$ k.k. w latach 2011-2016. W 2011 roku liczba wyroków skazujących za ten czyn zabroniony wynosiła 38, zaś w 2016 roku już $1086^{4}$.

Należy zauważyć, że regulacje dotyczące tzw. stalkingu powodują wiele problemów interpretacyjnych. Wynika to m.in. z użycia przez ustawodawcę niepotrzebnych zwrotów stanowiących dodatkowe znamiona czynu, będących powtórzeniem pewnych elementów wysłowionych w innych znamionach, braku definicji legalnych niektórych określeń czy też wątpliwości co do dokładnego zakresu zastosowania pewnych definicji legalnych. Zaburza to odbiór przepisów, co stanowi czynnik generujący problemy ze stosowaniem tych przepisów w praktyce. Zasadne jest więc przeprowadzenie analizy znamion występków wysłowionych w art. 190a $\S$ 1 i $\$ 3$ k.k., z uwzględnieniem i szerszym omówieniem kwestii problematycznych w toku wykładni ów przepisów, celem ułatwienia zrozumienia tychże przepisów, co pozwoli stosować je lepiej w praktyce. Analiza taka pozwoli również na wysnucie wniosków co do zasadności regulowania penalizacji występku uporczywego nękania w przyjęty przez ustawodawcę sposób i umożliwi sformułowanie postulatów de lege ferenda $\mathrm{w}$ omawianym zakresie.

\section{TYP PODSTAWOWY PRZESTĘPSTWA UPORCZYWEGO NĘKANIA}

Przestępstwo uporczywego nękania w typie podstawowym ustawodawca stypizował w art. 190a § 1 k.k., zgodnie z którym: „kto przez uporczywe nękanie innej osoby lub osoby jej najbliższej wzbudza u niej uzasadnione okolicznościami poczucie zagrożenia lub istotnie narusza jej prywatność, podlega karze pozbawienia wolności do lat 3". Z racji wymiaru kary, która w swej dolnej granicy jest niższa aniżeli 3 lata wolności (gdyż wynosi w swej dolnej granicy jeden miesiąc pozbawienia wolności), przestępstwo uporczywego nękania należy zakwalifikować jako występek.

Omawiane przestępstwo jest przestępstwem powszechnym, z racji użycia przez ustawodawcę zaimka „kto”. Z kolei, w aspekcie strony podmiotowej, zauważyć należy, że występki stypizowane w art. 190a § 1 popełnić można wyłącznie umyślnie, zarówno w zamiarze bezpośrednim jak również w zamiarze ewentualnym ${ }^{5}$. Sąd Najwyższy zauważył również, że w przypadku przestępstwa uporczywego nękania nie jest istotna motywacja sprawcy (czy jego działania motywowała np. miłość,

4 Skazania prawomocne - z oskarżenia publicznego - stalking art. 190a kk w latach 2011-2016, Informator Statystyczny Wymiaru Sprawiedliwości, https://isws.ms.gov.pl/pl/baza-statystyczna/ opracowania-wieloletnie/download,2853,42.html (dostęp: 9.03.2019 r.).

5 N. Kłączyńska, [w:] Kodeks karny. Część szczególna. Komentarz, J. Giezek (red.), Warszawa 2014, s. 471-472. 
niechęć czy nienawiść żywiona do pokrzywdzonego $)^{6}$. Opisywane przestępstwo umiejscowione zostało w rozdziale XXIII k.k. Pozwala to dojść do wniosku, że przedmiotem ochrony jest wolność człowieka. Jak zauważa A. Golonka wolność $\mathrm{w}$ omawianym przypadku powinna być pojmowana w znaczeniu jakie nadają ów wolności normy prawne, a w szczególności normy prawne znajdujące się w Konstytucji ${ }^{7}$. M. Mozgawa precyzuje pojmowanie owej wolności wskazując, że wolność chroniona przez art. 190a k.k. może być wolnością „do czegoś” (np. do zachowania swojej prywatności), ale także wolnością „od czegoś” (przede wszystkim od bycia nagabywanym przez inną osobą, wolność od strachu) ${ }^{8}$. W aspekcie strony przedmiotowej analizowany występek można popełnić przez działanie, jednak nie ma takich przesłanek, które wykluczałyby popełnienie go również przez zaniechanie $^{9}$. Nadto przestępstwo stypizowane w art. 190a $\S 1$ zaliczyć można do kategorii przestępstw skutkowych, gdyż do ich popełnienia potrzebny jest skutek w postaci wzbudzenia u pokrzywdzonego uzasadnionego poczucia zagrożenia lub istotnego naruszenia prywatności pokrzywdzonego.

Uporczywe nękanie może objawiać w różnych formach, choćby poprzez: obdarowywanie pokrzywdzonego niechcianymi przez niego prezentami, ciągłe wysyłanie wiadomości SMS (często o niepożądanej treści), śledzenie, „czatowanie” na osobę nękaną przed jej domem, składanie gróźb karalnych czy też nachodzenie w miejscu pracy ${ }^{10}$. Powoduje to, że wolność człowieka nie jest jedynym dobrem prawnie chronionym naruszanym przez sprawcę. W konsekwencji uznać należy za przedmiot ochrony również zdrowie, nietykalność cielesną ${ }^{11}$, tajemnicę korespondencji (z racji tego, że niektóre formy uporczywego nękania, mogą zawierać w sobie naruszenie ów tajemnicy) oraz prywatność.

Istotne znaczenie w omawianym przepisie ma zwrot „uporczywe nękanie”. Słowo „nękanie” nie posiada jakiejkolwiek definicji legalnej. Dlatego też w niniejszym opracowaniu celem odpowiedniej analizy omawianej problematyki należy posługiwać się derywacyjną koncepcję wykładni prawa. Zgodnie z regułami przytoczonej koncepcji w przypadku braku definicji legalnej należy odwołać się do definicji słownikowej danego wyrażenia ${ }^{12}$. W internetowej wersji słownika PWN wyraz „nękać” definiowany jest jako „ustawicznie dręczyć kogoś” ${ }^{13}$. Z kolei w „Słow-

6 Postanowienie SN z dnia 12 grudnia 2013 r., III KK 417/13, KZS 2014, nr 6, poz. 26.

7 A. Golonka, Uporczywe nękanie jako nowy typ czynu zabronionego, „Państwo i prawo” 2012, nr 1, s. 89.

8 M. Mozgawa [w:] Kodeks karny. Komentarz, M. Mozgawa (red.), Warszawa 2015, s. 507.

9 A. Golonka, op. cit., s. 91.

${ }^{10}$ Ibidem, s. 88.

11 Ibidem, s. 90.

${ }^{12}$ M. Zieliński, Wyktadnia prawa. Zasady, reguty, wskazówki, Warszawa 2017, s. 295.

${ }_{13}$ Słownik języka polskiego PWN, https://sjp.pwn.pl/sjp/nekac;2488262.html, (dostęp: 3.10.2017). 
niku języka polskiego” pod redakcją M. Szymczaka wyraz „nękać” znaczy tyle, co „ustawicznie dręczyć, trapić, niepokoić (czymś) kogoś”14. Natomiast zgodnie z „Małym słownikiem języka polskiego” pod redakcją E. Sobol nękać to „ustawicznie dręczyć, trapić, niepokoić kogoś; dokuczać komuś, nie dawać spokoju"15.

Aby mieć do czynienia ze znamieniem nękania, ów cykliczne zachowanie musi powodować dyskomfort psychiczny lub fizyczny, powodować przykrość czy też zadawać pokrzywdzonemu cierpienie ${ }^{16}$. Przykładami takich zachowań mogą być chociażby: wysyłanie pokrzywdzonemu niechcianych przez niego wiadomości SMS, wręczanie niechcianych upominków, ciągłe nagabywanie pokrzywdzonego czy też śledzenie go. W przypadku znamienia nękania, należy mieć na uwadze, że aby móc przyjąc realizację omawianego znamienia przez sprawcę, to ów sprawca musi nękać pokrzywdzonego wbrew jego woli ${ }^{17}$. Jak zauważył Sąd Najwyższy, ustawodawca nie wymaga, aby zachowanie sprawcy niosło za sobą element agresji ${ }^{18}$. Nadto, zachowania realizujące znamię nękania powinny być zakomunikowane pokrzywdzonemu bądź wyraźnie zrozumiałe dla otoczenia, w tym dla pokrzywdzonego ${ }^{19}$.

W myśl analizowanego przepisu nękanie ma być uporczywe. Co prawda, to znamię analogicznie jak znamię „nękanie” nie ma swojej definicji legalnej. Zgodnie z internetową wersją słownika PWN uporczywy znaczy to „trudny do usunięcia, utrzymujący się długo lub ciągle powtarzający się" ${ }^{20}$. W „Małym słowniku języka polskiego" uporczywy został zdefiniowany jako „trwający ciągle, nie przerywany, powtarzający się, nieustanny”21. Z kolei w „Słowniku języka polskiego” pod redakcją M. Szymczaka wyraz ,uporczywy” definiowany jest jako „trudny do usunięcia, zlikwidowania; utrzymujący się długo, uciążliwy"22. W kwestii uporczywości wypowiedział się również Sąd Najwyższy. Wskazał on, że znamię uporczywości składa się z dwóch elementów ${ }^{23}$. Pierwszy element charakteryzuje ,postępowanie sprawcy od strony podmiotowej, a polega na szczególnym nastawieniu psychicznym wyrażającym się w nieustępliwości, chęci postawienia na swoim (obojętne z jakich pobudek), podtrzymywaniu własnego stanowiska na przekór ewentual-

${ }_{14}$ Stownik języka polskiego. Tom drugi L-P, M. Szymczak (red.), Warszawa 1994, s. 317.

${ }_{15}$ Mały stownik języka polskiego, E. Sobol (red.), Warszawa 1993, s. 489.

16 A. Golonka, op. cit., s. 92.

17 J. Kosonoga [w:] Kodeks karny. Komentarz, R.A. Stefański (red.), Warszawa 2015, s. 1091.

18 Postanowienie SN z dnia 12 grudnia 2013 r., III KK 417/13, KZS 2014, nr 6, poz. 26.

19 M. Królikowski, A. Sakowicz [w:] Kodeks karny. Częśś szczególna. Tom I. Komentarz do artykutów 117-221, M. Królikowski, R. Zawłocki (red.), s. 541.

${ }^{20}$ Słownik języka polskiego PWN, https://sjp.pwn.pl/sjp/uporczywy;2533102.html, (dostęp: 4.10.2017).

${ }^{21}$ op. cit., E. Sobol (red.), s. 984.

22 Stownik języka polskiego. Tom trzeci, R-Z, M. Szymczak (red.), Warszawa 1994, s. 610.

${ }^{23}$ Sąd Najwyższy przeprowadzał wykładnię znamienia uporczywości w kontekście przestępstwa uporczywej niealimentacji. Jednak przedstawione wnioski można uznać za adekwatne również w przypadku występku z art. 190a § 1 k.k. 
nym próbom jego zmiany". Drugi element, będącym elementem obiektywnym, „polega na trwaniu takiego stanu rzeczy przez pewien dłuższy czas ${ }^{24}$. Aby więc mówić o uporczywości danego zachowania musi być ono cykliczne, wielokrotnie powtarzające się przez dłuższy określony czas. W kwestii znamienia uporczywości pojawiły się w doktrynie głosy, co do bezzasadności użycia ów znamienia. M. Mozgawa wskazuje, że wyraz ,uporczywe” w omawianym przepisie stanowi superfluum ustawowe ${ }^{25}$. Cytowany autor argumentuje swój pogląd, wskazując, że już w samej definicji słowa „nękać”, zawarty jest warunek uporczywości. Nadto M. Mozgawa twierdzi także, że implikowanie dodatkowych wymagań ustawowych $\mathrm{w}$ postaci znamienia uporczywości, powodować będzie stosowanie omawianego przepisu w praktyce ${ }^{26}$. Należy zauważyć, że wedle wskazanej wcześniej definicji nękanie to ustawiczne dręczenie kogoś. Zgodnie z Internetową Słownikiem Języka Polskiego PWN wyraz „,ustawiczny” znaczy tyle co, „ciągły, nieprzerwany”27. W „Małym słowniku języka polskiego” wyraz ,ustawiczny” definiowany jest jako „,bezustanny, ciągły, nieprzerwany”28. Z kolei, w „Słowniku języka polskiego” pod redakcją M. Szymczaka wyraz ,ustawiczny” znaczy tyle, co „ciągły, nieprzerwany, stały”29. W konsekwencji można uznać wyrazy „,ustawiczny” i ,uporczywy” w zakresie znaczeniowym właściwym dla omawianego przepisu za synonimy. Uporczywość, więc zawarta jest w definicji nękania. Konsekwencją tego wniosku, jest to, że ujęcie w przepisie znamienia uporczywości powoduje powtórzenie znamienia uporczywości jakie można wywieść z definicji wyrazu „nękanie”. W konsekwencji słuszne jest twierdzenie M. Mozgawy, że użyte przez ustawodawcę w omawianym przepisie znamienia uporczywości należy uznać za superfluum ustawowe. Jednak $\mathrm{z}$ racji powtórzenia znamienia uporczywości w warstwie deskryptywnej ów przepisu nie można mówić, tak jak twierdzi cytowany autor, o nałożeniu dodatkowych wymagań ustawowych. Wynika to z tego, że dodanie zwrotu ,uporczywy” w podanym przepisie jest powtórzeniem znamienia uporczywości ${ }^{30}$, które zawiera się w definicji słowa „nękanie”. W konsekwencji powtórzenie czegoś nie dodaje de facto nowych wymagań, a tworzyć może jedynie pewien pleonazm, źle wpływający na odbiór tekstu prawnego. Pleonazm ten co prawda może nie wpływa nazbyt negatywnie na stosowanie tego przepisu w praktyce, ale celem realizacji zasady nullum crimen sine lege certa wskazane jest usunięcie znamienia uporczywości $\mathrm{z}$ analizowanego przepisu.

\footnotetext{
${ }^{24}$ Uchwała SN z dnia 9 czerwca 1976 r., VI KZP 13/75, OSNKW 1976, Nr 7-8, poz. 86, pkt. 3.

${ }_{25}$ M. Mozgawa, op. cit., s. 507.

26 Ibidem, s. 507.

27 Słownik języka polskiego PWN, https://sjp.pwn.pl/sjp/ustawiczny, (dostęp: 4.10.2017).

${ }^{28}$ Op. cit., E. Sobol (red.), s. 990.

${ }^{29}$ Op. cit., M. Szymczak (red.), s. 624.

${ }^{30}$ Innymi słowy też znamienia ustawiczności.
} 
Przy omawianiu znamienia uporczywego nękania zasadnym jest odniesienie się przepisów, z którymi art. 190a $\S 1$ k.k. pozostaje w zbiegu, a mianowicie do art. 207 § 1 i 1a k.k. oraz art. 107 k.w. ${ }^{31}$. Pierwszy i drugi z tych przepisów penalizują znęcanie się nad osobą najbliższą, pozostającej w stosunku zależności (art. 207 § 1 k.k.), a także nad osobą nieporadną (art. 207 § 1a k.k.). Natomiast art. 107 k.w. penalizuje złośliwe niepokojenie innej osoby. Intuicyjnie wydaje się, że zakresy normowania obu przepisów są zbieżne, co powoduje istotne problemy przy ustalaniu kwalifikacji prawnej in concreto. W aspekcie relacji pomiędzy art. 190a §1 a art. $207 \S 1 \mathrm{i} \S 1 \mathrm{a}$ k.k. istotne jest ustalenie stosunku pomiędzy nękaniem a znęcaniem się. Jak wskazuje P. Kozłowska-Kalisz wskazując na rozróżnienia między znęcaniem się a nękaniem wskazuje, że nękanie jest psychicznym znęcaniem się nad inną osobą ${ }^{32}$. Nadto, autorka wskazuje, że ,nękanie może mieć charakter mniej intensywny wymiar niż znęcanie" ${ }^{33}$. Niewątpliwe, nękanie można uznać za formę powodowania dolegliwości psychicznych u pokrzywdzonego, nie zaś dolegliwości fizycznych, co wynika m.in. z definicji nękania oraz przedstawionych, przykładowych sposobów nękania. Warto zaznaczyć, że problem kwalifikacji prawnej w przypadku udręczenia psychicznego sprawcy występuje wtedy, gdy przedmiotem czynności sprawczej jest jeden z podmiotów, o którym mowa w art. $207 \S 1$ i 1a k.k. W takim przypadku organ winien najpierw sprawdzić czy doszło do znęcania się psychicznego czy też fizycznego. Jeśli doszło do znęcania się psychicznego to należy wówczas zastosować kryterium ilościowe - jeśli nękanie było bardzo intensywne to należy zastosować kwalifikację prawną z art. $207 \S 1$ lub 1a, natomiast w wypadkach mniej intensywnych - art. 190a § 1. Dane przestępstwo należy w przypadku znęcania fizycznego należy zakwalifikować jako czyn z art. $207 \S$ 1 lub 1a, a jeśli dochodzi do znęcania zarówno psychicznego jak i fizycznego to wówczas organ winien rozważyć czy nie doszło do zbiegu przepisów.

Odnosząc się natomiast do art. 107 k.w., to problem stanowi kwalifikacja danego kompleksu zachowań jako nękania lub złośliwego niepokojenia. Jak wskazuje P. Furman zakresu obu nazw krzyżują się ${ }^{34}$. Tworzy to wątpliwości co do kwalifikacji danego zachowania się. Wydaje się, że w tym przypadku należy zbadać stopień społecznej szkodliwości czynu sprawcy. W przypadku gdy stopień społecznej szkodliwości czynu jest większy niż znikomy, to wówczas należy zakwalifikować dane zachowanie jako przestępstwo $\mathrm{z}$ art. 190a § 1 k.k. Natomiast $\mathrm{w}$ drobniejszych przypadkach zastosowanie winien mieć art. 107 k.w.

${ }^{31}$ Ustawa z dnia 20 maja 1971 r. - Kodeks wykroczeń (Dz.U. z 2018 r., poz. 618), dalej: k.w.

32 P. Kozłowska-Kalisz [w:] M. Mozgawa (red.) Stalking, Warszawa 2018, s. 82.

33 Ibidem, s. 82.

${ }^{34}$ P. Furman, Próba analizy konstrukcji ustawowej przestęstwa uporczywego nękania z art. 190 a k.k. Zagadnienia wybrane, „Czasopisma Prawa Karnego i Nauk Penalnych” 2012, z. 3, s. 63. 
Ustawodawca wskazuje, że ów uporczywe nękanie dotyczyć ma innej osoby albo osoby najbliższej dla tej „innej osoby”. Pojęcie „osoby najbliższej” ustawodawca zdefiniował w art. $115 \S 11$ k.k., zgodnie, z którym „osobą najbliższą jest małżonek, wstępny, zstępny, rodzeństwo, powinowaty w tej samej linii lub stopniu, osoba pozostająca w stosunku przysposobienia oraz jej małżonek, a także osoba pozostająca we wspólnym pożyciu”. Niewątpliwie, pojęcie to odnosi się do konkubinatu, a więc do związku dwóch osób o różnej płci ${ }^{35}$. W uchwale składu siedmiu sędziów z dnia 25 lutego 2016 r. SN stwierdził, że „zawarty w art. 115 $\S 11$ k.k. zwrot «osoba pozostająca we wspólnym pożyciu» określa osobę, która pozostaje $\mathrm{z}$ inną osobą $\mathrm{w}$ takiej relacji faktycznej, w której pomiędzy nimi istnieją jednocześnie więzi duchowe (emocjonalne), fizyczne oraz gospodarcze (wspólne gospodarstwo domowe).”. Ponadto SN wskazuje, że „odmienność płci osób pozostających $\mathrm{w}$ takiej relacji nie jest warunkiem uznania ich za pozostających we wspólnym pożyciu w rozumieniu art. $115 \S 11$ k.k." ${ }^{36}$. SN rozszerzył więc zakres nazwy „osoba pozostająca we wspólnym pożyciu” na partnerów życiowych pokrzywdzonego tej samej płci co pokrzywdzony. Jednocześnie wskazał cechy wspólnego pożycia, które są cechami charakteryzującymi konkubinat. Powoduje to dość istotne wątpliwości, co do trafności przedstawionego poglądu. Jednakże, szczegółowa analiza tego problemu przekracza ramy niniejszego opracowania. Warto zaznaczyć, że z pragmatycznego punktu widzenia pogląd SN wydaje się być słuszny, ponieważ na gruncie art. 190a $\S 1$ k.k. takie rozumienie innej osoby najbliższej umożliwia objęciem zakresem kryminalizacji nękania partnera pokrzywdzonego tej samej płci co pokrzywdzony celem wzbudzenia u pokrzywdzonego poczucia zagrożenia lub naruszenia jego prywatności, co pozwala zapewnić lepszą ochronę dóbr chronionych przez normy art. 190a § 1 k.k. Jak wskazuje M. Jachimowicz normy art. 190a § 1 k.k. nie obejmują ochroną osób, które nie można uznać za osoby najbliższe w rozumieniu prawnym, natomiast będących takimi osobami w rozumieniu faktycznym. Jako przykład osób najbliższych w rozumieniu faktycznym przywołany autor podaje przykład niezamieszkujących ze sobą narzeczonych $^{37}$. To rozwiązanie przyjęte przez ustawodawcę nie zapewnia pełnej ochrony przed nękaniem, bowiem abstrahuje ono od faktu, że poprzez nękanie takiej osoby również można wzbudzić poczucie zagrożenia u pokrzywdzonego lub naruszyć jego prywatność. Jednak należy mieć na względzie, że w przypadku innej osoby najbliższej w rozumieniu faktycznym, nie będącą jedną z osób, o której mowa w art. $115 \S 11$ k.k., mogą pojawić się trudności dowodowe w wykazaniu relacji

35 Zob. A. Szelęgiewicz, Stalking i przywłaszczenie tożsamości w polskim prawie karnym zagadnienia wybrane, „Ius Novum” 2013, nr 3, s. 70.

${ }^{36}$ Uchwała siedmiu sędziów SN z dnia 25 lutego 2016 r., sygn. I KZP 20/15, OSNKW 2016/3/19.

${ }_{37}$ M. Jachimowicz, Przestępstwo stalkingu w świetle noweli do kodeksu karnego, „Wojskowy Przegląd Prawniczy" 2011, nr 3, s. 45. 
pomiędzy tą osobą a pokrzywdzonym, bowiem w takiej sytuacji najistotniejszą rolę odgrywają uczucia jakie żywią do siebie te osoby, których nie da się w pełni obiektywnie zbadać. Zaś inne kryteria oceny relacji pomiędzy tymi osobami mogą być zawodne. W przypadku osób, o których mowa w art. 115 § 11 k.k. znacznie łatwiej jest udowodnić pokrewieństwo, powinowactwo czy też fakt wspólnego pożycia. Dlatego przyjęte rozwiązania nie jest rozwiązaniem idealnym, jednak stanowi przejaw racjonalności ustawodawcy.

Kolejnym ze znamion wskazanych w przepisie jego wzbudzenie u pokrzywdzonego uzasadnionego okolicznościami poczucia zagrożenia. $Z$ warstwy deskryptywnej omawianego przepisu odczytać można, że nie każda sytuacja wzbudzenia zagrożenia będzie realizacją ustawowych znamion. Ustawodawca używając zwrotu „uzasadnione okoliczności” wskazuje na obiektywizację stanu wewnętrznego odczuwanego przez pokrzywdzonego, jakim jest poczucie zagrożenia. Owe uzasadnienie dotyczyć ma okoliczności zachowania sprawcy ${ }^{38}$. Jak wskazuje J. Kosonoga ,przesłanką odpowiedzialności jest w tym przypadku poczucie zagrożenia, jakie powstałoby w danych okolicznościach u przeciętniej, racjonalnie myślącej osoby”. Wówczas ,reakcja taka powinna być w tych okolicznościach uznana za naturalną" ${ }^{39}$. Słuszność ma cytowany autor twierdząc, że oprócz przyjmowania obiektywnych przesłanek należy brać pod uwagę również właściwości psychiczne sprawcy (a więc również przesłanki subiektywne) ${ }^{40}$. Sąd Najwyższy zauważa nadto, że „dla bytu tego przestępstwa [z art. 190a § 1 k.k. - przyp. M.G.] nie ma znaczenia, czy sprawca ma zamiar wykonać swoje groźby”. Wskazuje również, że „,[dla bytu przestępstwa uporczywego nękania - przyp. M.G.] decydujące jest tu subiektywne odczucie zagrożonego, które musi być oceniane w sposób zobiektywizowany"41. Z kolei w wyroku z dnia 9 grudnia 2002 roku Sąd Najwyższy zauważa, że „kryterium, że subiektywne odczucie obawy przez zagrożonego jest uzasadnione, należy ujmować obiektywnie, lecz z uwzględnieniem osobowości zagrożonego. Innymi słowy, obawa zagrożonego, że groźba do niego skierowana będzie spełniona, jest wtedy uzasadniona, jeżeli każdy człowiek o podobnej do zagrożonego osobowości i w podobnej sytuacji również odczuwałby obawę przed taką groźbą"42. Przyjęcie, że przy rozpatrywaniu realizacji omawianego znamienia zarówno kryteriów subiektywnych jak i obiektywnych uznać należy za rozwiązanie optymalne. Odmienny pogląd polegający na przyjęciu, że realizacja znamion występuje wyłącznie w przypadku wystąpienia kryteriów subiektywnych (tj. wystąpienie samego poczucia zagrożenia spowodowanego zachowaniem się sprawcy) nadmiernie rozszerzyłoby

\footnotetext{
38 J. Kosonoga, op. cit., s. 1091.

39 Ibidem, s. 1091.

40 Ibidem, s. 1092.

41 Postanowienie SN z dnia 12 grudnia 2013 r., III KK 417/13, KZS 2014, nr 6, poz. 26.

42 Wyrok SN z dnia 9 grudnia 2002 r., IV KKN 508/99, LEX nr 75496.
} 
zakres regulacji, powodując, że niemalże każde wywołanie poczucia zagrożenia zachowaniem się sprawcy byłoby naruszeniem normy sankcjonowanej wysłowionej w art. 190a $\S 1$ k.k., zaś przyjęcie odpowiedzialności wyłącznie na podstawie kryteriów obiektywnych, nie byłoby rozwiązaniem adekwatnym, ponieważ w pewnym stopniu abstrahowało się by się od osoby pokrzywdzonego, a w konsekwencji nie doszłoby do rekompensaty za wyrządzone pokrzywdzonemu przez sprawcę zła, zaś ów rekompensata jest jednym z istotnych elementów systemu prawa karnego.

Ostatnim ze znamion wskazanym w art. 190a $\S 1$ k.k. jest znamię istotnego naruszenia prywatności. Znamię to opiera się wyłącznie na przesłankach obiektywnych, jednak nadal występuje pewien element ocenny ${ }^{43}$. Ustawodawca nie formułuje w k.k. definicji legalnej tego pojęcia, nadto nie występuje ono nazbyt często w polskiej ustawie karnej ${ }^{44}$. W k.k. nie sformułowano również jakiegokolwiek katalogu zachowań naruszających prywatność, co jest zapewne związane $\mathrm{w}$ pewnym stopniu z brakiem definicji legalnej pojęcia prywatności w ustawie karnej. Dlatego też należy odnieść się do doktrynalnego pojmowania prywatności. Wartym przytoczenia jest pogląd M. Budyn-Kulik i M. Mozgawa zgodnie, z którym ,prywatność to termin, który - w najszerszym znaczeniu - określa możliwość jednostki lub grupy osób do utrzymania swych danych oraz osobistych zwyczajów i zachowań nieujawnionych publicznie”. Nadto, „,prywatność często rozpatrywana jest jako prawo przysługujące jednostce" 45 . M. Budyn-Kulik i M. Mozgawa zaznaczają, że „elementem prywatności jest również swoboda wchodzenia w kontakty społeczne i ich utrzymywanie". Cytowani autorzy wskazują, że ich zdaniem sądzić można, że na gruncie art. 190a § 1 k.k. istotę prywatności stanowić będą dwa elementy. Pierwszym z nich, zdaniem tychże autorów, jest decydowanie o przepłynie informacji na temat własnej osoby. Drugim zaś, swobodne dysponowanie własnym postępowaniem ${ }^{46}$. Z kolei, M. Królikowski i A. Sakowicz wyliczają przykładowy katalog zachowań stanowiących naruszenie prywatności. Spowodowanie skutku naruszania prywatności, jak wskazują w ów wyliczeniu cytowani autorzy może polegać na ,nagrywaniu, filmowaniu, fotografowaniu, upublicznianiu wizerunku bez zgody [pokrzywdzonego - przyp. M.G.], narzucaniu swojego towarzystwa, innym przekraczaniu bariery fizycznej bliskości" ${ }^{\prime 4}$. Istotny jest także fakt, że ochrona prywatności nie ma charakteru absolutnego. Nie możemy mówić o realizacji znamienia naruszenia prywatności, jeśli dana osoba wyrazi zgodę na naruszenie

${ }^{43}$ M. Królikowski, A. Sakowicz, op. cit., s. 543.

${ }^{44}$ Odniesienie do prywatności można znaleźć wyłącznie w art. 213 § 2 k.k.

${ }_{55}$ M. Kulik-Budyn, M. Mozgawa, Prawnokarne i kryminologiczne aspekty nękania, Warszawa 2012, s. 12, https://www.iws.org.pl/pliki/files/IWS_BudynKulik\%20M\%2CMozgawa\%20M_aspekty\%20n\%C4\%99kania.pdf, (dostęp: 9.10.2017).

${ }^{46}$ M. Kulik-Budyn, M. Mozgawa, op. cit., s. 13.

47 M. Królikowski, A. Sakowicz, op. cit., s. 543. 
ów prywatności ${ }^{48}$. Wynika to z przyjęcia przez doktrynę obowiązywania pozaustawowego kontratypu zgody pokrzywdzonego ${ }^{49}$. Nadto, jak wskazuje J. Kosonoga, naruszenie prywatności mogą wyłączać przepisy szczególne (dotyczące przykładowo przeszukiwania, zatrzymania czy cenzury w rozumieniu art. $105 \S 4$ k.k.w. ${ }^{50}$, a także przepisów dotyczących kontroli i utrwalania rozmów telefonicznych) ${ }^{51}$.

Ustawodawca, jak już powiedziano, wskazuje, że naruszenie prywatności musi być istotne. W kwestii tej wypowiedział się Sąd Apelacyjny w Krakowie stwierdzając, że istotność wymaga żeby naruszenie dóbr prawnie chronionych ,wedle przeciętnych ocen przyjmowanych w społeczeństwie przekracza próg dozwolonych zachowań i nie jest małej wagi”'52. Z kolei M. Budyn-Kulik i M. Mozgawa wskazują, że ustawodawcy tworząc omawiany przepis chodzić mogło o wyłączenie spod zakresu normowania sytuacje naruszające prywatności w sposób mało istotny ${ }^{53}$.

Cytowani powyżej autorzy ponadto sygnalizują, że można zastanawiać się nad koniecznością wprowadzania do tegoż przepisu znamienia istotności, z racji tego, że sytuacje naruszenia prywatności w sposób mało znaczący mogłyby być rozpatrywane przez pryzmat art. $1 \S 2 \mathrm{k} . \mathrm{k} .{ }^{54}$. Twierdzenie wspomnianych autorów wydaje się być twierdzeniem zasadnym. Każde zachowanie się człowieka mogące być przestępstwem, jest oceniane przez pryzmat struktury przestępstwa. W ramach owej struktury przestępstwa bada się także społeczną szkodliwość czynu. Jeśli społeczna szkodliwość czynu jest niewielka to wówczas nie zostaje spełniony jeden z elementów tejże struktury. W konsekwencji, jeśli naruszono określone dobro prawne (w tym wypadku naruszono prywatność innej osoby) w sposób nieistotny, a więc nie powodujący dla pokrzywdzonego znacznych negatywnych skutków, to wówczas jest spełniony warunek znikomej społecznej szkodliwości. Ustawodawca używając w art. 190a § 1 k.k. słowa ,istotnie”, wskazuje, że ładunek społecznej szkodliwości naruszenia prywatności pokrzywdzonego musi być większy niż znikomy, co jest poniekąd powtórzeniem normy zawartej w art. $1 \S 2$ k.k. Owe powtórzenie więc należy zakwalifikować jako superfluum ustawowe. Dlatego zasadne jest usunięcie z warstwy deskryptywnej art. 190a § 1 k.k. znamienia istotności.

48 Analogicznie nie zostanie zrealizowane znamię uporczywego nękania, jeśli osoba nękana wyrazi zgodę na zachowania ją nękające.

49 J. Kosonoga, op. cit., s. 1091.

${ }^{50}$ Ustawa z dnia 6 czerwca 1997 r. - Kodeks karny wykonawczy (Dz.U. z 1997 r., nr 90, poz. 557 ze zm.).

51 J. Kosonoga, op. cit., s. 1091.

${ }^{52}$ Wyrok SA w Krakowie z dnia 28 października 2010 r., I ACa 908/10, LEX nr 743278.

${ }^{53}$ M. Kulik-Budyn, M. Mozgawa, op. cit., s. 13-14.

54 „Nie stanowi przestępstwa czyn zabroniony, którego społeczna szkodliwość jest znikoma”. 


\section{TYP KWALIFIKOWANY PRZESTĘPSWA UPORCZYWEGO NĘKANIA - ART. 190A § 3 K.K.}

Zgodnie z art. 190a § 3 k.k. ,jeżeli następstwem czynu określonego w $§ 1$ lub 2 jest targnięcie się pokrzywdzonego na własne życie, sprawca podlega karze pozbawienia wolności od roku do lat 10". Z racji użycia przez ustawodawcę sformułowania ,jeśli następstwem jest”, należy stwierdzić, że występek, o którym mowa $\mathrm{w}$ omawianym przepisie jest typem kwalifikowanym przez następstwo.

Zasadnicze znaczenie na gruncie omawianego przepisu ma znamię targnięcia się pokrzywdzonego na własne życie. Kwestia ta rozpatrywana jest w doktrynie na gruncie art. 151 k.k., jednak rozważania co do tego znamienia w kontekście przytoczonego artykułu będą adekwatne również w przypadku art. 190a $\S 3$ k.k. Jak wskazuje K. Burdziak targnięcie się na własne życie należy rozumieć jako odebranie sobie życia przez człowieka ${ }^{55}$. W konsekwencji stwierdzenie „targnięcie się na własne życie”, jest co do zasady równoznaczne ze słowem „samobójstwo”, które zgodnie z jedną ze słownikowych definicji znaczy „,celowe odebranie sobie życia" ${ }^{56}$. Celowość działania samobójczego jest przedmiotem sporu w doktrynie, w szczególności, gdy rozpatrywane są przez targnięcia się na swoje życie przez osoby nieletnie lub niepoczytalne, zaś ów targnięcie się jest skutkiem doprowadzenia do tego przez inną osobę za pomocą namowy lub udzielenia pomocy. Jednak rozwiewanie wspomnianych wątpliwości nie mieści się w zakresie niniejszego opracowania. Trzeba dodać, na co wskazuje przytoczony powyżej autor, że rozumienie pojęcia „targnięcie się na własne życie” nie można ograniczać wyłącznie do samobójstwa dokonanego ze skutkiem pozytywnym. Przez to pojęcie należy rozumieć także usiłowanie odebrania sobie życia przez człowieka ${ }^{57}$. W przypadku omawianego przepisu, przez pojęcie „człowiek” należy rozumieć pokrzywdzonego. Poczynione uwagi, pozwalają stwierdzić, że na gruncie przestępstwa z art. 190a § 3 k.k. zwrot „targnąć się na własne życie” rozumieć należy jako dokonanie przez pokrzywdzonego występkiem uporczywego nękania bądź usiłowania dokonania samobójstwa, na skutek popełnienia tego przestępstwa na szkodę pokrzywdzonego. Regulacja ta jest podobna do art. $207 \S 3$ k.k. penalizującego doprowadzenie do targnięcia się na własne życie pokrzywdzonego na skutek znęcania się nad nim przez sprawcę.

${ }^{55}$ K. Burdziak, Przedmiot czynności wykonawczej przestępstwa z art. 151 kodeksu karnego, „Acta Iuris Stetinensis” 2015, nr 10 (861), s. 24.

${ }_{56}$ Słownik języka polskiego PWN, https://sjp.pwn.pl/sjp/samobojstwo;2519017.html, [dostęp: 16.10.2017].

${ }^{57} \mathrm{~K}$. Burdziak, Kierowanie wykonaniem samobójstwa i polecenie jego wykonania w prawie karnym, „Ruch Prawniczy, Ekonomiczny i Socjologiczny” 2014, z. 4, s. 178. 
Warto odwołać się do art. 151 k.k. zgodnie z którym „kto namową lub przez udzielenie pomocy doprowadza człowieka do targnięcia się na własne życie, podlega karze pozbawienia wolności od 3 miesięcy do lat 5". Jego omówienie nie należy, co prawda do zakresu niniejszego opracowania, niemniej istotne dla omawianej problematyki będzie zestawianie przytoczonego przepisu z art. 190a $\S 3$ k.k. Znamienia udzielenia pomocy wysłowionego w art. 151 k.k. nie da się powiązać z występkiem penalizowanym w art. 190a $\S 3$ k.k., a co za tym idzie nie będzie on przedmiotem analizy. Znamię doprowadzenia kogoś do targnięcia się na własne życie należy rozumieć jako powodowanie targnięcia się pokrzywdzonego na swoje życie (w najprostszym ujęciu, które nie jest w pełni trafne) ${ }^{58}$. Zaś znamię namowy ma wiele elementów wspólnych z podżeganiem ${ }^{59}$. Jak wskazuje Ł. Pohl namowa ta może przybrać jakąkolwiek formę (np. słów, gestu, wydawania określonych dźwięków czy też znaków), która skłoni namawianego do pożądanego przez namawiającego działania (lub zaniechania ${ }^{60}$. W konsekwencji można zastanawiać się czy uporczywe nękanie można uznać za namowę, o której mowa w art. 151 k.k. Przyjęcie takiego poglądu powodowałoby, że art. 190a § 3 k.k. prima facie można byłoby uznać za zbędny. Biorąc pod uwagę przytoczony sposób realizacji namowy należy stwierdzić, że zakres zachowań jakim ów namowy można dokonać jest szeroki. Przez to jeśli celem sprawcy, dla którego uporczywie nękał pokrzywdzonego, albo przywłaszczał jego tożsamość było, aby doprowadzić ów pokrzywdzonego za pomocą namowy do tego, aby targnął się on na swoje życie, to wówczas możemy stwierdzić, że przez popełnienie tychże przestępstw zrealizowane zostało znamię „namowy”. Konsekwencją tego, jest możliwość przyjęcia popełnienia występku stypizowanego w art. 151 k.k. Jednak, jeśli sprawca nie działał w celu doprowadzenia do targnięcia się pokrzywdzonego na jego życie, to wówczas ów skutek został wywołany nieumyślnie przez co sprawca nie będzie mógł zostać pociągnięty do odpowiedzialności karnej z art. 151 k.k. Nadto, penalizowane przez art. 151 k.k. nie będzie działanie nieumyślne, gdyż ów występek można popełnić wyłącznie umyślnie $\mathrm{w}$ zamiarze bezpośrednim, a także $\mathrm{w}$ zamiarze ewentualnym ${ }^{61}$. Przestępstwo z art. 190a $§ 3$ k.k. należy do przestępstw typu umyślno-nieumyślnego, przez co ustawodawca nie wymaga, aby wywołanie skutku w postaci targnięcia się pokrzywdzonego na jego życie było spowodowane przez sprawcę umyślnie ${ }^{62}$. Przez to niezależnie od tego czy sprawca chciał, przewidywał bądź nie wystąpienie skutku w postaci targnięcia się pokrzywdzonego na swoje życie, ów sprawca może zostać pociągnięty do odpowiedzialności karnej. W tym aspekcie art. 190a

\footnotetext{
58 Ibidem, s. 177.

59 Ibidem, s. 180.

60 Ł. Pohl, Prawo karne. Wykład części ogólnej, Warszawa 2015, s. 165.

61 R. Kokot [w:] op. cit., R.A. Stefański (red.), s. 874.

62 M. Budyn-Kulik, M. Mozgawa, op. cit., s. 19.
} 
$\S 3$ k.k. jest względniejszy więc dla pokrzywdzonego. Jak już wskazano art. 151 i art. 190a § 3 k.k. mają zbieżne zakresy normowania, bowiem penalizują doprowadzenie innej osoby do targnięcia się na własne życie. Przy czym, art. 151 k.k. jest regulacją szerszą, penalizującą spowodowanie tego skutku za pomocą namowy lub udzielenia pomocy suicydentowi. Z kolei art. 190a $\S 3$ k.k. penalizuje wyłącznie namowę do popełnienia zamachu samobójczego w postaci nękania suicydenta. Kolejną różnicą jest sankcja karna, która w przypadku przestępstwa z art. 190a $\S$ 3 k.k. jest wyższa, gdyż wynosi od roku do 10 lat kara pozbawienia wolności, zaś za czyn z art. 151 k.k. ustawodawca przewiduje karę pozbawienia wolności od 3 miesięcy do lat 5 . A co za tym idzie, czyn z art. 190a $§ 3$ k.k. cechuje się wyższym ładunkiem społecznej szkodliwości niż czyn z art. 151 k.k. Pozwala to stwierdzić, że przestępstwo $z$ art. 190a $§ 3$ k.k. stanowi typ kwalifikowany czynu z art. 151 k.k., zaś znamieniem kwalifikującym jest forma namowy suicydenta, czyli nękanie go.

\section{PODSUMOWANIE}

Przestępstwo uporczywego nękania polega na powodowaniu dolegliwości odbijających się na psychice sprawcy. W związku z tym udowodnienie tego przestępstwa jest dość problematyczne. Ustawodawca co prawda dokonał obiektywizacji znamienia istotnego poczucia zagrożenia, jednak mamy tutaj do czynienia z procesami psychicznymi, których udowodnienie zawsze będzie obarczone jakimś ryzykiem. W art. 190a § 1 k.k. posłużono się znamieniem nękania nie definiując go ani nie wskazując chociażby otwartego katalogu zachowań, jakim można się dopuścić nękania. Wydaje się to być zabieg celowy, gdyż dzięki temu penalizowany jest każdy przypadek nękania. Wymaga to jednak dookreślenia pojęcia przez doktrynę i judykaturę. Problemy interpretacyjne sprawia również znamię innej osoby najbliższej, a w szczególności kwestia czy taką osobą może być partner życiowy pokrzywdzonego tej samej płci. Co prawda SN problem ten rozwiązał, jednak zasadne wydaje się doprecyzowanie tej kwestii w art. $115 \S 11$ k.k. Warto zastanowić się także nad możliwością wprowadzenia do tej definicji osób najbliższych w znaczeniu potocznym, np. narzeczonych nie zamieszkujących ze sobą oraz odpowiednich mechanizmów dowodowych celem weryfikacji, czy dana osoba i pokrzywdzeni są faktycznie związani ze sobą emocjonalnie. Ustawodawca przy konstrukcji art. 190a § 1 k.k. umieścił w przepisie zbędne znamiona uporczywości nękania oraz istotność naruszenia prywatności. Znamiona te de facto nie wpływają na karnoprawną ocenę danego zachowania przestępnego, lecz niekiedy mogą być problematyczne. W związku z tym niezbędne jest wyeliminowanie tych znamion z przepisu. Ponadto istotne problemy powstają z kwalifikacją prawną zachowań stanowiących nękanie. Problemem jest możliwa kwalifikacja zachowania przestępnego zarówno z art. 190a § 1 k.k. jak i art. 107 k.w., rzadziej zaś z art. 207 § 
1 lub 1a. Zasadne wydaje się tutaj wypracowanie algorytmów lub zastosowanie zaproponowanego w niniejszym opracowaniu modelu karnoprawnej.

Pozytywnie należy ocenić stworzenie typu kwalifikowanego art. 151 k.k., znajdującego się w art. 190a $§ 3$ k.k. Zarzutem jaki można uczynić względem tego przepisu jest sankcja karna, która $z$ niewiadomych powodów jest inna aniżeli $\mathrm{w}$ podobnym typie czynu zabronionego z art. $207 \S 3$ k.k. (która w przypadku doprowadzenia do targnięcia na własne życie znęcaniem się wynosi od 2 do 12 lat pozbawienia wolności). Zasadnym wydaje się podwyższenie sankcji z art. 190a $\S 3$ k.k., zwłaszcza biorąc pod uwagę fakt, że oba przestępstwa cechują się takim samym ładunkiem społecznej szkodliwości.

\section{BIBLIOGRAFIA}

Burdziak K., Kierowanie wykonaniem samobójstwa i polecenie jego wykonania w prawie karnym, „Ruch Prawniczy, Ekonomiczny i Socjologiczny” 2014, z. 4.

Burdziak K., Przedmiot czynności wykonawczej przestęstwa z art. 151 kodeksu karnego, „Acta Iuris Stetinensis" 2015, nr 10 (861).

Furman P., Próba analizy konstrukcji ustawowej przestęstwa uporczywego nękania z art. 190a k.k. Zagadnienia wybrane, „Czasopisma Prawa Karnego i Nauk Penalnych” 2012, z. 3.

Golonka A., Uporczywe nękanie jako nowy typ czynu zabronionego, „Państwo i prawo” 2012, nr 1.

Jachimowicz M., Przestępstwo stalkingu w świetle noweli do kodeksu karnego, „Wojskowy Przegląd Prawniczy" 2011, nr 3.

Kłączyńska N., [w:] Kodeks karny. Część szczególna. Komentarz, J. Giezek (red.), Warszawa 2014.

Kokot R. [w:] Kodeks karny. Komentarz, R.A. Stefański (red.), Warszawa 2015.

Kosonoga J. [w:] Kodeks karny. Komentarz, R.A. Stefański (red.), Warszawa 2015.

Kozłowska-Kalisz P. [w:] M. Mozgawa (red.) Stalking, Warszawa 2018.

Królikowski M., Sakowicz A. [w:] Kodeks karny. Część szczególna. Tom I. Komentarz do artykułów 117-221, M. Królikowski, R. Zawłocki (red.)

Kulik-Budyn M., Mozgawa M., Prawnokarne i kryminologiczne aspekty nękania, Warszawa 2012, https://www.iws.org.pl/pliki/files/IWS_BudynKulik\%20M\%2CMozgawa\%20M_aspekty $\% 20$ n\%C4\%99kania.pdf, [dostęp: 9.10.2017].

Mały słownik języka polskiego, E. Sobol (red.), Warszawa 1993.

Mozgawa M. [w:] Kodeks karny. Komentarz, M. Mozgawa (red.), Warszawa 2015.

Pohl Ł., Prawo karne. Wykład części ogólnej, Warszawa 2015.

Postanowienie SN z dnia 12 grudnia 2013 r., III KK 417/13, KZS 2014, nr 6, poz. 26.

Skazania prawomocne - z oskarżenia publicznego - stalking art. 190a kk w latach 2011-2016, Informator Statystyczny Wymiaru Sprawiedliwości, https://isws.ms.gov.pl/p1/baza-statystyczna/ opracowania-wieloletnie/download,2853,42.html [dostęp: 9.03.2019 r.].

Słownik języka polskiego PWN, https://sjp.pwn.pl/sjp/nekac;2488262.html, [dostęp: 3.10.2017].

Słownik języka polskiego PWN, https://sjp.pwn.pl/sjp/samobojstwo;2519017.html, [dostęp: 16.10.2017].

Słownik języka polskiego PWN, https://sjp.pwn.pl/sjp/uporczywy;2533102.html, [dostęp: 4.10.2017].

Słownik języka polskiego PWN, https://sjp.pwn.pl/sjp/ustawiczny, [dostęp: 4.10.2017].

Stownik języka polskiego. Tom drugi L-P, red. M. Szymczak, Warszawa 1994. 
Szelęgiewicz A., Stalking i przywłaszczenie tożsamości w polskim prawie karnym - zagadnienia wybrane, „Ius Novum” 2013, nr 3.

Uchwała siedmiu sędziów SN z dnia 25 lutego 2016 r., sygn. I KZP 20/15, OSNKW 2016/3/19.

Uchwała SN z dnia 9 czerwca 1976 r., VI KZP 13/75, OSNKW 1976, Nr 7-8, poz. 86, pkt. 3

Ustawa z dnia 25 lutego 2011 r. o zmianie ustawy - Kodeks karny (Dz. U. z 2011 r. Nr 72, poz. 381).

Ustawa z dnia 6 czerwca 1997 r. - Kodeks karny wykonawczy (Dz.U. z 1997 r., nr 90, poz. 557 ze zm.).

Uzasadnienie do projektu ustawy zmieniającej Ustawę z dnia 6 czerwca 1997 r. - Kodeks karny z 31 sierpnia 2011 r. (Sejm VI kadencji, druk nr 3553).

Wyrok SA w Krakowie z dnia 28 października 2010 r. I ACa 908/10, LEX nr 743278.

Wyrok SN z dnia 9 grudnia 2002, IV KKN 508/99, LEX nr 75496.

Zieliński M., Wykładnia prawa. Zasady, reguty, wskazówki, Warszawa 2017.

\section{SUMMARY}

This paper pictures the essence of the crime persistence harassment of fraud described in Article 190a of polish Criminal Code. This law regulations will be analysed aiming at show a comprehensions of meaning the terms used by legislator in this law regulations and also indication the problematic issues therein same mistake made by legislator when he constructed law regulations pertaining to crime of persistence harassment what makes that this law regulation includes some superfluous elements. Nonetheless elaborated law regulations should be deemed necessary despite of some mistakes.

Keywords: persistent harassment; laying violent hands on oneself; criminal code 